\title{
A CONTRASTIVE ANALYSIS OF RUSSIAN AND NORWEGIAN UTTERANCE-INITIAL COORDINATING CONJUNCTIONS
}

\author{
MARGJE POST \\ University of Bergen
}

\section{ABS TRACT}

In the study presented here, the three Russian basic additive and contrastive coordinating conjunctions $i, a$ and no were compared to their two Norwegian counterparts og and men when used in utterance-initial position. By means of a direct comparison of sentences from Russian and Norwegian novels and their translations, both differences between the languages and languageinternal boundaries between the conjunctions were made apparent. As a result of the study, a core meaning was formulated for each of the five conjunctions. According to the analysis presented here, the Russian conjunction a connects in a way fundamentally different from $i$ and no. Metaphorically speaking, $i$ and no can be said to connect on a horizontal, or syntagmatic, line, whereas a connects elements on a vertical, or paradigmatic axis. Unlike $i$ and no, the conjunction $a$ is implicationally unmarked for linear, logical connections. In Norwegian, og simply has an additive meaning, whereas men signals the existence of an element of conflict. These core meanings account not only for the use of these connectives in general, but they can also explain certain specific qualities and conditions for pragmatic use in utterance-initial position. An analysis in terms of core meanings needs to be supplied by contrastive studies on the basis of corpora, which show actual use of the words in almost all possible contexts.

\section{[1] INTRODUCTION}

This article presents a contrastive analysis of the counterparts of the basic additive and contrastive coordinating conjunctions and and but in Russian and Norwegian - the Russian coordinating conjunctions $i, a$ and no and Norwegian og and men. The aim of the study was to give a better understanding of the properties of each of these conjunctions, in particular when they are used as pragmatic connectives in utterance-initial position. In some pragmatic uses these words can have more in common with discourse particles than with conjunctions. For instance, turn-initial $a$ is usually considered to be a particle, cf. (Vasilyeva 1972; Rejmankova 1975; Rathmayr 1985; Šimchuk \& Ščur 1999). Much could be said about the 
conjunction or particle status of these utterance-initial connectives, but this topic will not be discussed here. For practical reasons the term conjunction will be used in this article to cover all uses, on a par with connective, which is meant as a general term for connecting words from a broader range of word classes.

For the present study a contrastive approach was chosen, because a comparison of two language systems demonstrates differences directly, not only differences between languages, but also boundaries between words in a single language system. As remarked by Jasinskaja \& Zeevat (2008), an important role in the distribution of functions over words is played by the systemic factor: in which contexts and in which functions a particular conjunction can be used depends in part on what other conjunctions are available in the system of that language. In order to find subtle differences in pragmatic use of these conjunctions, the study was supported by a comparison of the actual use of the words in sentences from novels with their translations in the other language.

One of the main goals of the current paper is to show what comparative studies based on corpora and other empirical data can contribute to the study of connectives. Most of this study was based on a limited set of sentences from four Russian and four Norwegian (bokmål) ${ }^{1}$ novels and their translations. ${ }^{2}$ From each novel 10-15 pages with relatively much dialogue were chosen. The resulting approx. 100 pages in each language contains a total of 460 Russian and 334 of the Norwegian utterance-initial conjunctions in question (Post 1997). The development of Russian monolingual and bilingual corpora, such as the Russian National Corpus (RNC) ${ }^{3}$ and the RuN corpus, a new Russian-Norwegian parallel corpus under development, ${ }^{4}$ makes the study of much larger amounts of data more feasible. Unfortunately, it has not been possible to include more than some preliminary results based on data from these corpora in this paper, but an attempt will be done to show the relevance of the use of corpora.

For Norwegians, with their dual system, the choice between the three conjunctions in Russian is not always easy. ${ }^{5}$ From a Norwegian, or English, point

[1] The Norwegian texts were restricted to the largest of the two Norwegian written standards, bokmål, because of the limited number of translations written in nynorsk.

[2] The eight novels and their translations represent six modern authors (two Norwegian and four Russian) and seven different translators (cf. Post (1997); the references below include most of them).

[3] The Russian National Corpus (RNC; русский национальный корпус) is a corpus consisting of a number of subcorpora, including monolingual Russian corpora of mainly written, but also transcribed spoken language, and two bilingual corpora: Russian-English and Russian-German (http://www.ruscorpora.ru).

[4] The RuN corpus is a Russian-Norwegian parallel translation corpus, consisting of mainly fictional texts and their translations, developed at the University of Oslo within the RuN project (http://www.hf.uio.no/ilos/forskning/forskningsprosjekter/run/).

[5] As a matter of fact, Russian has a fourth conjunction - $d a$ - and Norwegian a third one - enn, but they were not included in this study because of their low frequency and restricted distribution. Da is stylistically marked (for an extended description cf. Mendoza (1996)). The conjunction enn can in most varieties of Norwegian not introduce clauses, but only phrases in constructions like «Enn De, da, Levin?» («A вы, Левин?»; Л. Толстой; RuN corpus) 
of view, the conjunction $a$ is the odd one out. Russian utterance-initial $i$ usually corresponds to Norwegian og, and no to men, but the conjunction $a$ is about as often translated with additive og as with contrastive men. ${ }^{6}$ The exact boundaries between $a$ and $i$ and between $a$ and no have been an object for discussion for a long time, e.g. in Krejdlin \& Padučeva (1974a,b); Kručinina (1988); Sannikov (1989); Uryson (2002, 2004); Jasinskaja \& Zeevat (2008).

In both languages the conjunctions are frequently used in initial position, much more frequent than their counterparts in, for instance, English and Dutch; cf. Perridon (1987) . ${ }^{7}$ The utterance-initial conjunctions are often left untranslated. A sample of 400 question utterances starting with a in RNC's Russian-English corpus shows that less than $50 \%$ of these questions have a corresponding conjunction in English Røsstad (2009): 8

«А Собакевича знаешь?»

«Then you are acquainted with Sobakevitch?» (RNC, from Н. Гоголь )

- А что ж? - Да так-с!

«Well»? «Just so, sir,» he answered. (RNC, from M. Лермонтов)

«Listen, Nick; let me tell you what I said when she was born.»

- A хочешь знать, что я сказала, когда она родилась, Ник?

(RNC, from F. S. Fitzgerald)

In many cases a conjunction is even added, such as in (1) above, where $a$ turns up in the Russian translation of a sentence with no conjunction in the source language. Despite their widespread use and the fact that they are frequently not translated or not even translatable, utterance-initial $i, a, n o$, og and men have received little attention in the literature ${ }^{9}$ and the conditions for their pragmatic use in this position have not yet been described in detail.

[2] WHAT IS SPECIAL ABOUT UTTERANCE-INITIAL USE?

$I, a, n o, o g$ and men are coordinating conjunctions, i.e. in their prototypical use they connect two syntactically equal linguistic expressions to each other - words,

[6] This holds true only for the utterance-initial conjunctions, both in the sentences from the Russian novels that were gathered for the present study (see below) and in the RuN corpus. In general, $a$ corresponds more often to og than to men (RuN corpus).

[7] In two translations from Norwegian to Dutch of a novel by Knut Hamsun a substantial number of instances of initial og were omitted in Dutch, despite the general tendency of translators to keep close to the original (Cannegieter 1997). The use of utterance-initial og (och) and men appears to be even more frequent in Danish and Swedish than in Norwegian; cf. (Hulthén 1947, 176-178) and (Øyslebø 1978, 224). Perridon (1987) cites a passage from August Strindberg in which och introduces almost every sentence.

[8] The reason why Røsstad chose to compare Russian to English, and not to Norweian, is that the RuN corpus of Russian and Norwegian prose is still under development and does not yet allow searching for question utterances.

[9] An exception is Mendoza's monograph on pragmatic use of $i$, $a$ and $d a$ (Mendoza 1996). 
phrases or clauses. Utterance-initial use shows that this is not always the case: the first constituent can be expressed much earlier than the second constituent, or not be expressed at all, but only presupposed. Use as the first word in an utterance means that the word connects not on the level of the sentence, but that it is a pragmatic connective on discourse level. ${ }^{10}$ It also means that the connection is indirect: it is not immediately obvious which are the two elements that are being connected.

It is assumed that, on a mental level, coordinating conjunctions always express a link between two ideas or propositions. ${ }^{11}$ The term conjunct is used to denote the two mental units that are connected. Utterance-initial use of coordinating conjunctions shows that not necessarily both ideas are represented by a linguistic expression. Only a part of the information that the speaker (or writer) intends to convey has an explicit linguistic expression. This means that the first conjunct can be non-verbal, such as in the next example, where Men signals a contrast between the actual behaviour of the addressee and his/her expected behaviour:

(4) Med uvant klossethet brøt han inn i avskjeden idet moren sto og trykket damene i hånden. [...] Det lyktes ham å få forkortet seremonien til det minst mulige.

«Men Lillelord, jeg tror du er gal,» sa moren, »Det er de voksne som skal si adjø først, det vet du meget godt.» (Borgen 1955, 108)

С необычной для него неловкостью он вторгся между ними как раз в ту минуту, когда мать прощалась за руку с сестрами Воллкварц. [...] Ему удалось по возможности сократить церемонию.

- Маленький Лорд, что с тобой, ты не в своем уме! - сказала мать. Ты прекрасно знаешь, что сначала прощаются взрослые.

(Borgen 1979, 121) $)^{12}$

The coordinating conjunctions can even introduce a poem, a story, or even the title of a novel; the literature refers to several poems by Anna Achmatova (Kručinina 1988; Uryson 2002, 166) and to a short story by Kjell Askildsen (Øyslebø 1978). The title of one of the novels used for the current research actually starts with

[10] According to (Mendoza 1996, 57-58) all sentence-initial connectives, connecting across sentence boundaries, are pragmatic by definition, since every sentence consists of at least one speech act, and a connection is considered pragmatic if both conjuncts have their own illocution: «Eine Verknüpfung wird als pragmatisch bezeichnet, wenn beide Konjunkte eine eigene Illokution haben» $(1996,57)$.

[11] The reason for mentioning ideas in addition to propositions is that the connection triggering the use of the conjunctions can be associative and have little to do with propositional logic.

[12] Dutch has developed the same use of the contrastive conjunction as Norwegian: «Maar Kleine Lord, je bent niet wijs [...]» (Borgen [1983], 116) 
i: И дольше века длится день (Ajtmatov 1983a), translated with og in Norwegian (Ajtmatov 1983a). ${ }^{13}$

In certain contexts the connectives have a pragmatic function quite distinct from their basic function as an additive or contrastive conjunction of two clauses. They are closer to pragmatic particles and other discourse markers than to conjunctions, fulfilling pragmatic functions, thus guiding the hearer in how to link the utterances to the linguistic and extra-linguistic context. In certain pragmatic uses they are called 'pleonastic' ${ }^{14}$ or 'void of content ${ }^{15}$ in traditional reference books, such as the following construction in Norwegian, in (5), turning up in a translation from Russian (cf. section [6] below):

$$
\begin{aligned}
& \text { A я-то думал [...] (Rasputin 1984, 82) } \\
& \text { Og jeg som trodde [...] (Rasputin 1978, 91) }
\end{aligned}
$$

However, according to the analysis presented here, they are not void of content. Even in such cases they can be said to have an invariant, core meaning, as described in the next section, and make a contribution to the utterance, although not necessarily on a lexico-semantic level. Some examples of such pragmatic use will be discussed in section [6].

\section{[3] CORE MEANINGS}

As a result of the study (Post 1997, 1999b,a), a core meaning was formulated for each of the five conjunctions. These core meanings, or basic properties, apply for the conjunctions in general, so they are not confined to utterance-intitial conjunctions. Core meanings have also been formulated in earlier literature. Among the core meanings proposed for Russian a are juxtaposition (sopostavlenie; AG 1980) and distribution (a raspredelitel'noe; Kručinina 1988); Sannikov (1989) describes no as expressing «nesootvetstvie norme, narušenie normal'nogo choda sobytij» (1989, $153)^{17}$. However, in most descriptions a polysemy point of view is taken, and if

[13] As pointed out by the anonymous reviewer, the title of this novel is a citation from a poem by Boris Pasternak. In the original text, this verse does not introduce the poem, but is actually used only in the nineteenth line. Interestingly, the Norwegian translation has kept the conjunction in place, but the English and Dutch translations lack a conjunction: The Day Lasts More than a Hundred Years (Aitmatov 1980); De dag die langer duurde dan een eeuw (Ajtmatov 1995). Possibly, only the Norwegian translator was aware of the fact that this was a citation, but it could also be a sign of the lesser frequency of utteranceinitial use of coordinating conjunctions in English and Dutch as opposed to Russian and Norwegian.

[14] Beito (1986) refers to Norwegian og 'and' when starting a verse in folk songs or modern poetry as pleonastic ('eit pleonastisk og byrjar ofte ei line i folkeviser, stundom òg i nyare lyrikk'; (Beito 1986, 315)).

[15] The dictionary Nynorskordboka (NNO) on og 'som innhaldstom innleiing i visse utrop' on an example similar to (5). The counterpart dictionary of bokmål, Bokmålsordboka (BMO 2010) contains a very similar entry, but without the expression 'void of content'. In fact, og cannot be pleonastic and void of content in all respects, since the connective cannot be left out in the og jeg som-construction; cf. section [6] below.

[16] The Dutch translation contains the additive connective en in a full sentence: «En ik dacht nog wel [...]» (Raspoetin 1982, 111)

[17] I.e. no expresses a «divergence from the norm, a breach from the normal course of events». 
core meanings are given, they play a minor role. This accounts especially for Rus$\operatorname{sian} a$, which is almost always divided in three meanings, which are best known as (1) non-correspondence (a nesootvetstvija), (2) juxtaposition (a sopostavlenija) and (3) linking (a prisoedinitel'noe) (Krejdlin \& Padučeva 1974a). An exception is the monosemy approach in Jasinskaja \& Zeevat (2008).

The description given below was based on my own analysis and to a varying extent inspired by previous descriptions of coordinating conjunctions, including Prijatkina (1970); Krejdlin \& Padučeva (1974a,b); Girke (1978); Yokoyama (1981); Sannikov (1989) and others, and it is closest to Mendoza's description of $i$ and $a$ (1996), which is the only work focussing on pragmatic use. The description is also compatible with Jasinskaja \& Zeevat (2008)), although they take a different perspective. ${ }^{18}$ For an extensive overview of previous literature on the Russian conjunctions, see Mendoza (1996). More recent descriptions with interesting viewpoints about the boundaries between sentence-internal $i, a$ and no include Padučeva (1997); Uryson (2002, 2004); Zaliznjak \& Mikaeljan (2009); Jasinskaja \& Zeevat (2008).

The core meanings that were formulated as a result of the study (Post 1997, 1999b,a) are the following:

NORWEGIAN: In Norwegian, og simply has an additive meaning, whereas men signals the existence of an element of conflict.

RUSSIAN: In Russian, the conjunction $a$ is different from $i$ and no in the way the connection should be interpreted. Metaphorically speaking, $i$ and no can be said to add a proposition on a linear, horizontal, or syntagmatic line, whereas $a$ connects elements on a vertical, or paradigmatic axis. When $i$ and no are used, the relation between the two elements connected by the conjunction is interpreted cumulatively, usually on a time line or as a causal relation - with $i$ adding an element that is interpreted positively, and no introducing a deviation from the expected continuation. The conjunction $a$, however, is implicationally unmarked for such linear, logical connections (cf. Mendoza (1996) for an analysis of $i$ and $a$ along similar lines). ${ }^{19}$ The latter simply introduces a new member to an existing set, about

[18] Jasinskaja \& Zeevat (2008) give an interesting account of Russian i, $a$ and no and English and and but by presenting the connectives as topic management devices, introducing answers to different kinds of (implicit and explicit) questions under discussion.

[19] Mendoza describes $i$ as having a parallelisation effect (Parallellisierungseffekt): it can only connect conjuncts on the same semantic, thematic, argumentative or illocutive level $(1996,145,236)$. The same appears to apply for no, with the additional meaning that the second part represents a divergence from the norm. Furthermore, $i$ blocks an anti-iconic reading. This means that, if we call the structure « $i$ $Y »$ and $\mathrm{X}$ and $\mathrm{Y}$ are arguments of the structure, then $\mathrm{Y}$ cannot precede $\mathrm{X}$ neither temporally nor causally $(1996,108$; cf. Sannikov (1989) on no). "I und no haben [...] gemeinsam, daß sie die Konjunkte als abhängig repräsentieren $(н о)$ bzw. eine solche Interpretation nicht aussließen $(u)$. A hingegen initiiert keine Schlußfolgerungen über das logische Verhältnis der Konjunkte oder der in ihnen dargestellten Ereignisse.» (Mendoza 1996, 167) 
which something new is expressed or implied, without implying any causal link with the preceding context.

In the literature, the difference between $a$ and no in sentences where both can be used is often considered a difference in stylistics, with a representing a colloquial style. This difference can be explained by the proposed core meanings: logical, argumentative reasoning, strengthened by the use of no, is typical of prepared written texts, whereas associative thinking, supported by $a$, is more common in spontaneous speech.

The difference of $a$ from $i$ and no is reflected in sentence-internal information structure. In terms of the theory of actual sentence perspective (Krejdlin \& Padučeva 1974a,b), only $i$ and no can introduce rhemes (R); $a$ is typically followed by a pitch accented element that can be described as a new theme $(T){ }^{20}$ The connective a cannot be used to introduce rhematic predicates, coreferring to the same subject:

$$
\begin{gathered}
T \quad R_{1} \quad R_{2} \\
{\left[\text { OH] [встал], [подошел ко мне], } u /^{*} a\right. \text { [улыбнулся]. }} \\
\text { 'He stood up, walked towards me, } i /{ }^{*} a \text { smiled' (Yokoyama 1981) }
\end{gathered}
$$

A typical example of $a$ is the use of $a$ between two sets of theme-rheme pairs that are put up against each other; $\mathrm{cf}$. (7), from Berkov's Russian-Norwegian dictionary (2007):

$$
\begin{aligned}
& \text { a. } \quad \begin{array}{cccc}
T_{1} & R_{1} & T_{2} & R_{2}
\end{array} \\
& \text { Ru [Ты] [молод], } a \text { [он] [стар]. } \\
& \begin{array}{ccccc}
\text { b. } & T & R_{1} & T_{2} & R_{2} \\
& \text { No [Du] er [ung], men } & \{\text { og }\} & {[\text { han] }} & \text { er } \\
\text { [gammel] }
\end{array}
\end{aligned}
$$

The conjunction $a$ is also structurally different from $i$ and no. According to Prijatkina (1970), a cannot normally express a connection between two words by itself, without the help of another word or expression (1970, 190-191). This other word or expression is either an adverb, or adverbial expression, or another emphasised element, when $a$ connects two elements of the same category, as in the theme-rheme structures given above (Prijatkina 1970, 192-194). Thus, $a$ is strongly connected to the word or expression following immediately after it, which car-

[20] $T$ = theme; $R=$ rheme. Roughly speaking, the theme marks what the sentence is about; the rheme expresses what is being said about this theme and represents the most important communicative part of the sentence (Švedova et al. 1980, 91). 
ries a pitch-accent and often emphasis. In contrast, $a$ itself is unstressed and can normally not be followed by a pause.

[4] CORE MEANINGS ACCOUNT FOR UTTERANCE-INITIAL CONJUNCTIONS

The small data set of sentences from Russian and Norwegian novels shows that the proposed core meanings are valid even for the utterance-initial conjunctions. They can even explain many of the specific conditions for and constraints on pragmatic use in utterance-initial position, as will be argued below.

The following examples of the connectives introducing additional questions show a clear parallel to sentence-internal information structure. In (8), the waiter asks, after receiving a first order of four sweet pastries ${ }^{21}$ what else the guests would like to order:

(8) «Og sjokolade med krem?» (Borgen 1955, 109)

- И шоколад со сбитыми сливками? (Borgen 1979, 122)

The appropriate conjunction to introduce this additional question is $i$, because $i$ introduces a new element that corresponds to an addition to the rheme in the sentence «The guests $(=$ theme $\mathrm{T})$ would like to order four sweet pastries $(=$ rheme $\mathrm{R}_{1}$ ) and the guests (= same theme $\mathrm{T}$ ) would like to order hot chocolate with cream (= rheme $\mathrm{R}_{2}$ )».

In the wh-question in (9), however, the waiter's question introduces the second theme and asks for the content of the second rheme in a double theme-rheme pair « $\mathrm{T}_{1}$ orders $\mathrm{R}_{1}$, and $\mathrm{T}_{2}$ (= the young man) orders $\mathrm{R}_{2}$ (= unknown)»:

(9) «Og til den unge herre?» (Borgen 1955, 114)

- А для молодого человека? (Borgen 1979, 128)

The additive connective $i$ can generally be regarded as introducing a positive answer to a (real or presupposed) question, and no starts a negative answer, cf. Girke (1978); Jasinskaja \& Zeevat (2008). In the domain of narrative structure, $i$ is often used to start a positive (10) and no a negative continuation of the subtopic (11):

(10) «Kanskje vi skulle spise noe.»

Og det gjør de. (Borgen 1970, 54)

- Наверно, пора нам что-нибудь поесть.

И они едят. (Borgen 1979, 610)

(11) - Андрей, знаешь что?

- Что?

Но она передумала. - Ладно, потом. (Rasputin 1984, 80)

«Andrej, vet du hva?»

[21] «Fire wienerbrød?» (Borgen 1955, 109) 
«Hva?»

Men hun betenkte seg. «Det var ingenting, senere.» (Rasputin 1978, 89)

On the other hand, $a$ introduces not an answer, but something else, e.g. a change of perspective to a new subtopic (Mendoza 1996). In the next example, a introduces not a reaction, but a simple change of perspective:

(12) Ах, Сарала, ах, старина, мой славный конь, неужто жизнь так прекрасна, что даже в свой последний срок любить можно ...

A Сарала шагал дорожным ходом, пофыркивал, спеша домой, чтобы ногам дать отдых. (Ajtmatov 1983a, 439)

Akk, Sarala, akk du gamle, stolte hest, er livet virkelig så vidunderlig at man endog på sine siste dager kan få elske slik?...

Og Sarala gikk fram i skritt, prustet og skyndte seg hjem for å hvile bena. (Ajtmatov 1983b, 282-283) ${ }^{22}$

Similar to pragmatic particles (Foolen 2003 [1996]), the additive and contrastive conjunctions can signal the background or foreground status of a stretch of discourse. In argumentative discourse, $i$ typically introduces a new argument, no introduces counterarguments, whereas a introduces something else, typically, a digression from the line of reasoning. In narrative structure, $i$ and no add continuations to the current topic, whereas $a$ is used to introduce digressions from the current topic, (sub)topic shifts, or returns to a previous topic (cf. (Mendoza 1996)). I can also be used to return to the main story line after a short digression (13a), where the digression itself can be introduced by a (13b). Metaphorically speaking, $i$ continues the current line, whereas a introduces a transition to a new line:

А третий был то что у меня отец-то был межевой инженер//

a. $\quad$ А межевой инженер и геодезист это очень близко //

b. $\quad$ И его же знакомый преподавал / однокашник по межевому институту преподавал геодезиу там в лесном институте (Mendoza 1996, 179, cited from a text collection of transcribed spontaneous speech)

In this section most attention has been paid to the Russian conjunctions, because the Russian system is more complex. This does by no means mean that the Norwegian counterparts are too boring to be investigated. Norwegian og and men can

[22] Contrary to the Norwegian translation, $a$ was not translated in the Dutch translation (Ajtmatov 1995); cf. note (13). 
fulfill discourse structuring functions similar to Russian $a$ and $i$. Og can continue the story line, even at some distance in a new paragraph ${ }^{23}$ and a return to the main story line can be introduced by men. Men is also used at topic shifts. However, this does not mean that the Russian and Norwegian connectives always can be translated with each other whenever they fulfill similar functions. To show this, some examples will be discussed in section [6] below. A detailed contrastive analysis, however, with a precise demarcation of the pragmatic uses of the connectives, remains a task for future research.

\section{[5] NORWEGIAN AND RUSSIAN UTTERANCE-INITIAL USE COMPARED}

When comparing the Russian tripartite system to Norwegian, we expect that the distribution of $i, a$ and no over og and men is very simple: as a rule, men is chosen when there is an element of conflict that deserves attention, such as a contrast or a denial of expectation, whereas og is used to express simple addition. The difference between Russian $a$ and Norwegian og and men is shown in expressions where two sets of theme-rheme pairs are compared, as in (7), repeated below as (14). Unlike a speaker of Russian, a Norwegian language user has to express whether or not the difference between the pairs is in conflict with some expectation:

$$
\begin{array}{ccccc}
\text { a. } & \mathrm{T}_{1} \quad \mathrm{R}_{1} & \mathrm{~T}_{2} & \mathrm{R}_{2} \\
& \text { [Ты] [молод], } a \text { [он] [стар]. } \\
\text { b. } & \mathrm{T} \quad \mathrm{R}_{1} & \mathrm{~T}_{2} & \mathrm{R}_{2} \\
& \text { No [Du] er [ung], men }\{\text { og }\} \text { [han] er [gammel]. (Berkov 2007) }
\end{array}
$$

Below are two examples from the Russian and Norwegian novels: (15) introduces a positive reaction, (16) a negative one:

(15) $\quad$ Я [...] говорю: «Нюрка, это же генерал». А он мне: «Да, говорит, сынок, я и есть, говорит, генерал». (Pristavkin 1995, 11)

Jeg [...] sa: «Njurka, det er jo en general». Og han sa til meg: «Ja, gutten min, det er det jeg er, jeg er general». (Pristavkin 1991, 14)

(16) Он сказал подавленно: - Иди первый! Ты умный!

A Сашка ответил: - Ты тоже не дурак! Чего это я пойду?

(Pristavkin 1995, 166)

Han sa slukkøret: «Gå først! Du er flinkest!»

Men Sasjka svarte: «Du er ikke dum, du heller! Hvorfor skal jeg gå!»

(Pristavkin 1991, 208)

[23] Meaning no. 8 of och in the large dictionary of the Swedish Academy (SAOB 1898-) describes the use of och as introducing a new paragraph to mark that the first sentence is a direct continuation of the main presentation (topic), regardless of what has been mentioned in the immediately preceding context. Sometimes och changes into a general, comparatively neutral initial particle or initial interjection. 
In the excerpts from the Russian and Norwegian novels and their translations used for this study (see section [1] above), the two Norwegian connectives are a little less frequent than their three Russian counterparts. The least frequent utterance-initial connective is no, as could be expected, since this word has the most specific meaning. Russian a corresponds as often to og as to men, but in more than half of the utterances $a$ does not correspond to og or men in the Norwegian text. Norwegian og corresponds to $i$ in $45 \%$ of the sentences, and to $a$ in $31 \%$, the remaining $24 \%$ having no corresponding coordinating conjunction in the Russian texts.

In the RuN corpus the distribution is somewhat different: Russian $A$ is much less frequent and No much more frequent than in the novel excerpts. ${ }^{24}$ This is not surprising, because the excerpts in my own mini-corpus contain relatively much dialogue, in which utterance-initial $a$ is frequent, especially turn-initially.

The large number of non-correspondences in the translations is the topic of the next section.

\section{[6] BILINGUAL CORPORA REVEAL SPECIFIC USES}

Corpora can be used not only to find empirical support for predefined hypotheses. Just like cross-linguistic studies, they can also reveal unexpected properties of words that cannot be predicted from a general theory and that could remain unremarked in studies based on introspection. Corpus studies can reveal minor differences in the pragmatic uses of words, such as differences in possible contexts and in frequency.

In the mini-corpus of Russian and Norwegian novels, $35 \%$ of the sentenceinitial conjunctions did not correspond to a conjunction in the other language. ${ }^{25}$ So, in these cases, the translators deliberately chose not to translate the connectives with one of its counterparts in the target language, or they chose to add one in the translation. Part of these cases can be ascribed to the liberty of a translator of fiction to refrain from direct translations, but in other cases they reflect subtle pragmatic differences. In other cases, the use of a conjunction would even be infelicitous in the other language.

The core meanings described above cannot predict the exact conditions of use of pragmatic $i, a, n o, o g$ and men. Pragmatic uses in specific contexts are often

[24] As of April 2010, the RuN corpus, utterance-initial $i$ is used 4138 times, no - 3502 times and $a-2850$ times. The numbers for Norwegian are $5006(\mathrm{men})$ and $4298(\mathrm{og})$. The largest differences with the mini-corpus are that Norwegian og corresponds to $a$ in only $17 \%$ of its occurrences, but to $i$ in $60 \%$, and that men corresponds to no far more often (58\%) than to a (13\%), but even here the number of non-correspondences is substantial: $29 \%$. The RuN corpus gives the same proportions between utterance-initial $a$ and its Norwegian counterparts (see above): $23 \% \square-m e n, 25 \% a-$ og and 51\% non-correspondence.

[25] The numbers for the individual conjunctions lacking a corresponding conjunction in the other language were as follows: $50 \%$ of $i$ (including the small group of occurrences of the focus particle $i$ ), $53 \%$ of $a, 15 \%$ of no, $24 \%$ of og and $21 \%$ of men in initial position. 
conventionally based uses that are language-specific and have to be learnt by the language user. However, the proposed basic properties can help explain these specific uses, as shown by some examples in the remainder of this section.

In the following example, $a$ has been added to a question in the translation (cf. (1), (2), (3) above):

(17) Han sa: «Har du vært i Bretagne? Vi reiser til Bretagne.» (Borgen 1970, 111)

Он вдруг спросил:

- A ты бывала когда-нибудь в Бретани? Едем в Бретань!

(Borgen 1979, 658)

A high frequency of initial $a$ in questions can be expected because $a$ can introduce a new member to an existing set of questions, independent of temporal or causal links. Therefore, it can introduce almost any question. A possible explanation for the much lower frequency of og and men in questions is that the Norwegian connectives are too easily associated with temporal and causal links.

Even og and men remain untranslated in a substantial part of the sentences. In the following examples, men has discourse structuring functions. In (18), this word introduces a return to a previous topic after a long digression; in (19) it introduces a topic shift in a new paragraph:

(18) Men nå lurte han på hvem [...] (Holt 1975, 122-123)

Так вот, он теперь решил разузнать [...] (Cholt 1982, 282)

(19) Men nå skal du høre på meg. (Holt 1975, 126)

Теперь послушай, что еще скажу. (Cholt 1982, 285)

Although the Russian conjunctions can have similar functions, as we saw in section [4], and translations with $i$ in (18) and $a$ in (19) could actually have been possible, the translators chose for some reason it was better to leave out the conjunctions. In both cases the digressions were comparably long. Possibly, Russian $i$ allows a shorter digression than Norwegian men to be able to signal a return to the main topic. Other possible reasons for omitting men include the strong link of $i$ and no to temporal and causal relations, while $a$ can give too strong associations to comparisons between two situations if the context is favourable for such an interpretation, like here in (19), where $a$ would have been followed by the adverb teper' 'now', as a translation of Norwegian Men na.. ${ }^{26}$ The connective $a$ cannot in itself suggest temporal and causal relations (Mendoza 1996,167). This feature of $a$ restricts its ability to connect over larger distances, if the connection is of a

[26] This does not mean that $a$ can never be used after long pauses; cf. (17) «А ты бывала когда-нибудь в Бретани?» In this case, however, the context does not suggest temporal, causal or comparative relations. 
mainly temporal or causal nature. As remarked in section [5], this topic has not yet been studied thoroughly.

A trait of Norwegian that could remain unnoticed without consulting bilingual corpora is the frequent use of the answering particles $j a$, nei and jo in this language. Below are two examples, where the answering particles were added to the Norwegian text in translations from Russian:

$$
\begin{aligned}
& \text { «А по-вашему что??» } \\
& \text { «а, hva mener De?» (RuN corpus; from Б. Пильняк) } \\
& \text { «Однако пора уже» } \\
& \text { «Nei, men nå er det sandelig på tide å reise» (RuN corpus; from Л. Толстой) }
\end{aligned}
$$

$J a$,jo and nei often appear in combination with men. Ja and nei have even merged with men and developed into the discourse particles jammen, neimen (BMO). Of course, also in Russian the conjunctions in question have developed into idiomatic expressions in combination with other words, such as a to, described in Uryson (2008). These new idioms have developed their own meanings and functions. Therefore, they deserve separate studies.

Another example of the subtle differences between Russian and Norwegian shown in the novels is the frequent use of men in addresses in Norwegian, functioning as surprised reactions, of which (4) is an example («Men Lillelord!»). In these cases, men has no counterpart in the Russian parallel texts from the novel excerpts (22), nor in the translation from the example from Ibsen mentioned in a dictionary (RMO):

(22) - Men kjære deg, det er da bare uhyggelig. (Borgen 1955, 112)

- Милый, но ведь это ужасное место! (Borgen 1979, 125)

(23) brændt! Men du godeste Gud -! Nej, nej, nej, dette er rent umuligt! (Ibsen: Gabl., from RMO) Сожгла! Боже милосердный! .. Нет, нет, нет! Это невозможно! (Ибсен 1972, 616)

However, the construction occurred only three times in the mini-corpus, ${ }^{27}$ so larger data bases were required to find more attestations of this construction. The RuN corpus contains no more than a few examples. There were no occurrences of the conjunction $a$. Some examples contain no, but only in translations from Norwegian and invariably followed by a comma. ${ }^{28}$

[27] It also contained an example of «Ja men + [name]».

[28] Berkov's dictionary actually includes the addressing construction:

но, дорогой мой! men kjære Dem deg da! (Berkov 2007)

The RuN corpus indeed contains a few examples in the translations from Norwegian, e.g. «Но, Дина! Его же повесят!», translated from «Men Dina! De skal henge en mann!» (RuN corpus; from H. Wassmo). 
A check in RNC reveals absence of the conjunction $a$ and a very low frequency of no in addresses containing personal names, and in none of the cases of $a$, this word could be interpreted as a conjunction in an addressing construction. A does occur in addresses, but in these cases, $a$ is not related to the conjunction and it has a different prosody; cf. the following two examples from RNC:

$$
\begin{aligned}
& \text { «Наташ, а Наташ!» (RNC; from Ю. Трифонов) } \\
& \text { «А, Федя! Дома Хорь?» (RNC; from И. Тургенев). }
\end{aligned}
$$

In the few occurrences starting with no, this connective was followed by a comma. ${ }^{29}$ This suggests that the name used as an address was syntactically not part of the sentence introduced by no and that no probably was followed by a prosodic boundary, in which case no introduced not the name, but a sentence expressing a negation of an expected continuation. In Norwegian (as in Dutch) there is no prosodic boundary between the conjunction and the name; a boundary occurs only after the name..$^{30}$

The low occurrence of no in these constructions could be related to the strong connection with causality of no. Interestingly, the translation in (23) does contain no, but only after the address, introducing the expression of contrast itself. Men is first of all used to underline the speaker's surprise (cf. NNO 2010), and not necessarily to introduce the linguistic expression of a second, contrastive, conjunct.

A final example of a conventionally based use of an utterance-initial connective is the Norwegian contruction Og jeg som [...], literally 'And I who [...]', given earlier in (5), and in (26) below, both in translations from Russian:

$$
\begin{aligned}
& \text { «Og jeg som ventet på deg til klokken var to.» } \\
& -А \text { я тебя ждал до двух часов. (RuN corpus; from Л. Толстой) }
\end{aligned}
$$

It is a rather frequent syntactic elliptic construction with left dislocation of the subject, which is used to express surprise or indignation over a contrast between two situations or facts. ${ }^{31}$ This is obtained through juxtaposition of the situation involving the speaker with a previously activated situation by connecting them

[29] There is in fact a single example of no + a name, used as an address form without a preceding comma, but it was in free direct speech: Я глупо повторял про себя: Гонец из Пизы, из Ганы. Я был взбешен. Где же был этот хваленый рирайт, для чего, собственно, он нужен, как не для того, чтобы именно такие описки и исправлять! Но Оля! Что же вы-то, Оля, сплоховали с этим самым Константином? (RNC; from Н. Климонтович).

[30] However, as remarked by the anonymous reviewer, the presence of a comma does not necessarily imply the presence of a prosodic boundary in all of the Russian examples, since Russian punctuation is rather prescriptive.

[31] This og jeg som-construction is, of course, not restricted to the first person personal pronoun, but can also be used with other nouns and pronouns referring to persons. It is common in Swedish as well: SAOB describes it as introducing an ellipic sentence that consists of a noun or pronoun, determined by a following relative clause: "särskilt inledande en elliptisk sats som består av sbst. 1. pron., bestämt av en följande relativsats: Och jag, som letat så!" SAOB (1898-). 
with the additive connective og. At the current stage, the RuN corpus contains nine examples of this construction, all of which correspond to $a r$ [...] in Russian, often supported by a particle emphasising the pronoun. In Russian, what follows is not the Norwegian elliptic construction of a noun phrase with a subordinate clause, but a syntactically complete sentence. The occurrence of $a$ is expected, since the construction is comparative, putting up to pairs of alternatives against each other, comparable to two theme-rheme pairs.

\section{[7] CONCLUSION}

In the study presented above, the three Russian basic additive and contrastive coordinating conjunctions $i, a$ and no were compared to their two Norwegian counterparts $\mathrm{g}$ and men when used in utterance-initial position. A core meaning was formulated for each of the five conjunctions. According to the analysis presented here, the Russian conjunction $a$ connects in a way fundamentally different from $i$ and no. Metaphorically speaking, $i$ and no can be said to connect on a horizontal, or syntagmatic, line, whereas $a$ connects elements on a vertical, or paradigmatic axis. Unlike $i$ and no, the conjunction $a$ is implicationally unmarked for linear, logical connections. In Norwegian, og simply has an additive meaning, whereas men signals the existence of an element of conflict.

The small corpus of sentences from Russian and Norwegian novels used for this study shows that there are clear parallels between the basic, intrasentential use of the additive and contrastive conjunctions in Russian and Norwegian and their pragmatic use in utterance-initial position. Their basic properties account not only for their use in general, but they can also explain certain specific qualities and conditions for pragmatic use in utterance-initial position. The core meanings, or basic properties, of Russian $i, a$ and no and Norwegian og and men as proposed in this study help to explain why not all conjunctions are used in the same context with the same function. However, the formulation of a core meaning alone is insufficient for a good description of a word's meaning and functions, since a core meaning, which by necessity must be rather abstract, cannot predict the precise boundaries between two similar words, nor the exact conditions of use of a word. Therefore, an analysis of basic properties needs to be supplied by contrastive studies on the basis of corpora, which show actual use of the words in almost all possible contexts. These data show, for instance, that both the Russian and the Norwegian conjunctions can be used in the domain of narrative structure, introducing a continuation of the topic $(i, o g)$ or a return to a previous topic after a short digression ( $a$, men), but that their conditions for use in these functions do not fully coincide. The data from novels and their translations also show language-specific developments. For instance, Norwegian men is often combined with an address form, unlike its Russian counterparts, and in Norwegian, answering particles can be used as discourse particles, turning up in combination with 
og and men. The recent appearance of annotated corpora and the development of a Russian-Norwegian corpus will enable quick searches in large amounts of data to find empirical support for hypotheses and findings, and to reveal unexpected properties. Monolingual corpora, which for natural reasons are usually much larger than bilingual corpora, can supply evidence on lesser used words and constructions and answer questions whether certain contexts or constructions actually occur or not.

Many open questions remain to be addressed in future research. An interesting study would be a contrastive analysis of the Russian conjunctions and its counterparts in other Slavonic languages, which have different sets of additive and contrastive conjunctions (cf. Rejmankova 1975; Freidhof 1991; Gvozdanovič 1996), or with a comparison with Old Russian, with its frequent sentence-initial use of $a$ and $i$, for instance in the birch-bark letters (Zaliznjak 2004).

The number of occurrences analysed for the present study is too low to allow for a detailed analysis explaining all cases of pragmatic use. Therefore, the results presented in this article can only be considered preliminary. However, the analysis of the mini-corpus and the first results from the study of the larger corpora reveal some interesting first results, showing the usefulness of corpora for this kind of linguistic studies.

\section{ACKNOWLEDGMENTS}

The author wishes to thank the anonymous reviewer for useful comments.

\section{[8] PRIMARY SOURCES}

Aitmatov, Ch. 1980. The Day Lasts More than a Hundred Years. Translated into English by F. J. French. Bloomington: Indiana University Press

Ajtmatov, Č. 1983a. I dol'še veka dlitsja den'. In Sobranie sočinenij v trech tomach. Moscow: Molodaja gvardija

Ajtmatov, T. 1983b. Og dagen varer lenger enn et århundre. Translated from Russian into Norwegian by E. Kolstad. Oslo: Tiden

Ajtmatov, T. 1995. De dag die langer duurde dan een eeuw. Translated from Russian into Dutch by M. Weijers. Breda: De Geus

Borgen, J. 1955. Lillelord. Roman. Oslo: Gyldendal

Borgen, J. 1970. Vi har ham nå. [s.l.]: Den norske bokklubben 
Borgen Ju. 1979. Malen'kij Lord. Temnye istočniki. Teper' emu ne ujti. Translated from Norwegian into Russian by Ja. Jachnina and S. Tarchanova. Moscow: Progress

Borgen, J. [1983]. De Kleine Lord. Translated from Norwegian into Dutch by R. Schoorl. Weesp: Agathon

Cholt, K. 1982. Morskoj geroj. Translated from Norwegian into Russian by L. Ždanova. In Trizna po ženščine. Morskoj geroj: Romany. Moscow: Raduga Holt, K. 1975. Sjøhelten. Oslo: Gyldendal

Ibsen, G. 1972. Dramy. Stichotvorenija. Plays translated from Norwegian into Russian by A. and P. Ganzen. Moscow: Chudožestvennaja literatura

Pristavkin, A. 1991. Nattely for en gyllen sky. Translated from Russian into Norwegian by E. Egeberg. Oslo: Gyldendal

Pristavkin, A. 1995. Nočevala tučka zolotaja. In Izbrannaja proza. Moscow: Kvadrat

Raspoetin, V. 1982. Vlucht naar de wouden. Translation from Russian into Dutch by A. Pries. Amsterdam: De arbeiderspers

Rasputin, V.1978. Aldriglemme. Translated from Russian into Norwegian by G. Opeide. Oslo: Gyldendal

Rasputin, V. 1984. Živi i pomni. In Izbrannye proizvedenija v dvuch tomach. Tom 2. Moscow: Molodaja gvardija

RNC = Russian National Corpus (Русский национальный корпус), www.ruscorpora.ru

RuN corpus $=$ Russian-Norwegian Parallel Corpus, http://www.tekstlab.uio.no/glossa/html/index_dev.php?corpus=run

\section{REFERENCES}

Beito, O. T. 1986. Nynorsk grammatikk. lyd-og ordlæere. Oslo: Det norske samlaget.

BMO. 2010. Bokmålsordboka: definisjons- og rettskrivningsordbok. Oslo: Kunnskapsforlaget. www. dokpro.uio.no/ordboksoek.html. 
Cannegieter, M. 1997. Analyse av stilforskyvninger $i$ to nederlandske oversettelser av Knut Hamsuns roman 'Under høststjernen' (1906). Universiteit van Amsterdam MA thesis.

Foolen, A. 2003 [1996]. Pragmatic particles. In J. Verschueren, J.-O Östman \& Ch. Bulcaen (eds.), Handbook of pragmatics online, www.benjamins.com/online/ hop/.

Freidhof, G. 1991. Umgangssprachliche Eröffnungssignale in Dialogen der Schönen Litteratur (Narrative Prosa). In K. Hartenstein \& H. Jachnow (eds.), Slavistische Linguistik 1990 (= Slavistische Beiträge 274), 71-97. München.

Girke, W. 1978. Sätze mit no, $i$ und $a$. In W. Girke \& H. Jachnow (eds.), Slavistische linguistik 1977, 7-26. München.

Gvozdanovič, J. 1996. 'and' has four different correlates in western south slavic. Studies in South Slavic and Balkan Linguistics ( = Studies in Slavic and General Linguistics 23) 24. 101-109.

Hulthén, L. 1947. Studier i jämförande nynordisk syntax ii, vol. LIII. Göteborg: Göteborgs Högskolas Årsskrift.

Jasinskaja, K. \& H. Zeevat. 2008. Explaining Additive, Adversative and Contrast Marking in Russian and English. Revue de Sémantique et Pragmatique (24). 65-91.

Krejdlin, G. E. \& E. V. Padučeva. 1974a. Vzaimodejstvie associativnych svjazej i aktual'nogo členenija v predloženijach s sojuzom a. Naučno-techničeskaja informacija 2(10). 32-37.

Krejdlin, G. E. \& E. V. Padučeva. 1974b. Značenie i sintaktičeskie svojstva sojuza a. Naučno-techničeskaja informacija 2(9).31-37.

Kručinina, I. N. 1988. Struktura i funkcii sočinitel'noj svjazi v russkom jazyke. Moscow.

Mendoza, I. 1996. Zur Koordination im Russischen: $\boldsymbol{i}$, a, und da als pragmatische Konnektoren (= Slavistische Beiträge 338). München: Otto Sagner.

NNO. 2010. Nynorskordboka. definisjons- og rettskrivingsordbok. Oslo: Det norske Samlaget. www. dokpro.uio.no/ordboksoek.html.

Padučeva, E. V. 1997. Ėgocentričeskaja semantika sojuzov a i no. In V. S. Efimova T. M. Nikolaeva \& I. Fougeron (eds.), Slavjanskie sočinitel'nye sojuzy, 36-47. Moscow.

Perridon, H. 1987. 'och' en 'og'. een kontrastieve studie naar het gebruik van de voegwoorden zweeds 'och', deens 'og' en nederlands 'en'. Tijdschrift voor Skandinavistiek 8(1). 3-39. 
Post, M. 1997. I, A, No, Og en Men: over zinsinleidende voegwoorden in het Russisch en het Noors. Universiteit van Amsterdam MA thesis.

Post, M. 1999a. I, A i No v sopostavlenii s sosedstvujuščimi sojuzami v germanskich jazykach. In O. Kovačičova et al. (eds.), Russkij jazyk, literatura i kul'tura na rubeže vekov, vol. I, 140-141. Bratislava: IX meždunarodnyj kongres MAPRJaL. Tezisy dokladov i soobščenij.

Post, Margje. 1999b. A, I og No mot Og og Men: en kontrastiv undersøkelse av tre russiske og to norske konjunksjoner i setningsinnledende posisjon. Nordlyd 27. $24-43$.

Prijatkina, A. F. 1970. Konstruktivnye osobennosti sojuza a v prostom predloženii russkogo jazyka. In T. P. Lomtev \& A.A. Kamynina (eds.), Issledovanija po sovremennomu russkomu jazyku: sbornik statej, posvjaščennyj pamjati e.m. galkinojfedoruk, 190-205. Moscow.

Rathmayr, R. 1985. Die russische Partikeln als Pragmalexeme. (= Slavistische Beiträge 187).

Rejmankova, L. 1975. Ob upotreblenii častic pri osuščestvlenii svjazi meždu replikami. Československá rusistika 16-19.

Røsstad, K. 2009. En korpusundersøkelse av konjunksjonen a i russiske originaltekster og i oversatte tekster. Bergen. University of Bergen MA thesis.

Sannikov, V. Z. 1989. Russkie sočinitel'nye konstrukcii: Semantika. Pragmatika. Sintaksis. Moscow: Nauka.

SAOB. 1898-. Ordbok över svenska språket. Lund: Utgiven av Svenska Akademien. http://g3.spraakdata.gu.se/saob/.

Uryson, E. V. 2002. Sojuz A kak signal «povorota povestvovanija». In N. D. Arutjunova (ed.), Logičeskij analiz russkogo jazyka: Semantika načala i konca., 348-357. Moscow.

Uryson, E. V. 2004. Sojuzy A i NO i figura govorjaščego. Voprosy jazykoznanija 2004 (6).

Uryson, E. V. 2008. Sojuzy A TO i A NE TO: Počemu v nekotorych kontekstach oni sinonimičny. In Trudy meždunarodnoj konferencii «Dialog 2008». Moscow, 530-538. http://www .dialog-21.ru/dialog2008/materials/pdf/82.pdf.

Vasilyeva, A. N. 1972. Particles in colloquial Russian. Progress.

Šimchuk, E. \& M. Ščur. 1999. Slovar' russkikh častic. Peter Lang AG. 
Švedova, N. Ju et al. 1980. Grammatika russkogo jazyka. vol. i, ii. Moscow: Nauka.

Yokoyama, O. T. 1981. On sentence coordination in Russian: A functional approach. In R. A. Hendrik, C. S. Masek \& M. F. Miller (eds.), Papers from the seventeenth regional meeting of the Chicago Linguistic Society. Chicago, 431-438.

Øyslebø, O. 1978. Stil-og språkbruksanalyse. Oslo.

Zaliznjak, A. A. 2004. Drevnenovgorodskij dialekt. http://gramoty .ru/?id=dnd.

Zaliznjak, A. A. \& I. Mikaeljan. 2009. Russkij sojuz A kak lingvospecifičeskoe slovo. In Dialog 2005. Trudy meždunarodnoj konferencii. Retrieved 13, vol. 12., http://www.dialog-21.ru/Archive/2005/Zalizniak_Mikaelian/ Zalizniak_Mikaelian.pdf.

AUTHOR CONTACT INFORMATION

Margje Post

Institutt for framandspråk

Universitetet i Bergen

Postboks 7805, 5020 Bergen

Norway

Margje.Post@if.uib.no 